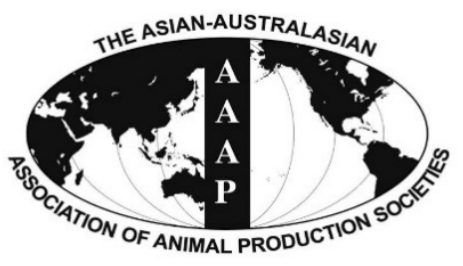

Open Access

Asian Australas. J. Anim. Sci.

Vol. 29, No. 9 : 1300-1308 September 2016

http://dx.doi.org/10.5713/ajas.16.0108

Www.ajas.info

pISSN 1011-2367 elSSN 1976-5517

\title{
Effectiveness of Phytogenic Feed Additive as Alternative to Bacitracin Methylene Disalicylate on Hematological Parameters, Intestinal Histomorphology and Microbial Population and Production Performance of Japanese Quails
}

\author{
M. Manafi*, M. Hedayati, and S. Khalaji \\ Department of Animal Science, Faculty of Agricultural Sciences, Malayer University, Malayer 65719-95863, Iran
}

\begin{abstract}
This study was conducted to evaluate the effects of phytogenic additive and antibiotic growth promoter in laying Japanese quails. One hundred and sixty five quails were divided into three groups of 5 replicates and 11 quails ( 8 females and 3 males) in each replicate. Treatment 1 was fed control diet, treatment 2 was fed control diet supplemented with $0.05 \%$ bacitracin methylene disalicylate as antibiotic growth promoter and treatment 3 was fed control diet supplemented with $0.1 \%$ phytogenic feed additive (PFA) for two periods of 3 weeks each from 37 to 42 weeks of age. Results showed that egg production, eggshell strength, eggshell weight, villus height and villus height to crypt depth ratio were significantly $(\mathrm{p} \leq 0.05)$ increased and feed consumption, feed conversion ratio, albumen, Haugh unit, cholesterol, low-density lipoprotein, alanine transaminase, gamma glutamyltransferase, alkaline phosphatase, high-density lipoprotein, triglyceride, number of goblet cell, crypt depth and intestinal bacterial population of Coliforms, Salmonella and E. coli were significantly $(\mathrm{p} \leq 0.05)$ decreased in PFA fed group. It is concluded that addition of PFA containing phytomolecules and organic acids as main ingredients could significantly improve the production parameters and the general health of laying quails as an alternative to antibiotic growth promoters. (Key Words: Feed Antibiotic, Blood Constituents, Performance, Phytogenic Feed Additive, Japanese Quails)
\end{abstract}

\section{INTRODUCTION}

Due to the growing demand for the use of herbal ingredients in human daily food, a tendency to minimize the chemical feed additives in poultry diets is among the interests of the producers. Considering the ban of feed antibiotics in many countries including Iran, their removal from the diet may negatively affect profitability of the animals (Manafi, 2015).

The beneficial effects of different bioactive compounds are found to enhance poultry productivity. The term 'phytogenic compound' refers to the plant parts (e.g. garlic, oregano, thyme, rosemary, coriander, and cinnamon) as well as to their respective extracts in the form of essential oils.

\footnotetext{
* Corresponding Author: M. Manafi. Tel: +98-81-32355416, E-mail: manafim@malayeru.ac.ir

Submitted Dec. 15, 2015; Revised Mar. 8, 2016; Accepted May 10, 2016
}

Many beneficial properties of phytogenic compounds originate from their bioactive molecules (e.g. carvacrol, thymol, cineole, linalool, anethole, allicin, capsaicin, allylisothiocynate, and piperine) (Grashorn, 2010). A large number of in vitro and in vivo studies have established a wide range of phytobiotic activities in poultry nutrition like stimulation of feed consumption (FC), antimicrobial, coccidiostatic, anthelmintic, immunestimulating (Manafi, 2015) antibacterial and antioxidant functions (Windisch et al., 2008), enhancement of digestive enzyme activities (Jamroz et al., 2006), positive effects on performance and feed conversion ratio (FCR), quality and carcass meat safety and lowering the levels of cholesterol, low-density lipoprotein (LDL) and high-density lipoprotein (HDL) (Stanaćev et al., 2011) in birds.

Recently, rearing of quail has gained importance in the poultry industry. The consumption of quail eggs and meat has significantly increased and there is scope for increasing 
healthy quail products in the market. Quail meat has extremely low skin fat and low cholesterol value. It is rich in micronutrients and a wide range of vitamins including the $\mathrm{B}$ complex, $\mathrm{E}$ and $\mathrm{K}$ and folate. The effects of individual essential oils have been studied earlier in quails; however, to the author's knowledge, there have been limited studies investigating the effects of bioactive components combination in laying quails. Therefore, this study was planned and performed to investigate the effects of phytomolecules bioactive compounds (allicin, peppermint, thymol, and carvacrol) and organic acids (propionic acid and fumaric acid) in comparison with antibiotic growth promoter in production performance, serum biochemistry, illeal bacterial status, immune response and intestinal morphology of Japanese laying quails.

\section{MATERIALS AND METHODS}

\section{Experimental birds and diets}

One hundred and sixty five layer Japanese quails (Coturnixcoturnix japonica) at 37 weeks of age with average initial body weight of $224 \pm 5 \mathrm{~g}$ were divided into 3 treatment groups, with 5 replicates and 11 quails ( 8 females and 3 males) in each replicate. Data were recorded from the quail when they were aged between 37 to 39 and 40 to 42 weeks, according to Malayer University approved animal care rules and protocols. Quails were housed in thermostatically controlled batteries $(152.4 \times 45.6 \times 26.7 \mathrm{~cm})$ with raised wire floors in an environmentally controlled building having forced air ventilation for 6 weeks duration. Treatment groups were fed a corn-soybean meal basal diet (control); control plus $0.05 \%$ bacitracin methylene disalicylate (BMD) and control plus $0.1 \%$ phytogenic feed additive (PFA). The PFA used in this study was Natusol, a combination of phytomolecules bioactive compounds (allicin, peppermint, thymol, and carvacrol) and organic acids (propionic acid and fumaric acid) from natural sources, provided by a commercial company (Zeus Biotech Limited, Mysore, India). The basal commercial quail breeder diet was fed as mash and prepared with the same batch of ingredients. Diet was formulated isonitrogenic and isoenergic. The ingredients and chemical composition of the coccidiostat-free basal diets are shown in Table 1. All quails were fed ad libitum feed and water throughout the study period and exposed to $17 \mathrm{~h}$ light. The PFA and BMD were procured from local market in powder form and added on top to the basal diet and were included into the basal diet according to experimental treatments. The feeding and collection protocols used in the present experiment were approved by the bioethical committee of Malayer University (protocol No. 84/5-1-246) under the guidelines of animal protection used for experimental and other scientific purposes. The quails were also raised and cared
Table 1. Ingredients and chemical composition of the basal diet of layer Japanese quail ( 37 to 42 weeks of age)

\begin{tabular}{lc}
\hline Item & $\%$ \\
\hline Maize & 38.00 \\
Soybean meal $(44 \% \mathrm{CP})$ & 25.00 \\
Sunflower meal $(34.7 \% \mathrm{CP})$ & 10.00 \\
Meat-bone meal $(58.5 \% \mathrm{CP})$ & 2.00 \\
Barley & 12.70 \\
Vegetable oil & 4.00 \\
Dicalcium phosphate & 0.4 \\
Limestone & 7.300 \\
Sodium chloride & 0.30 \\
Vitamin premix ${ }^{2}$ & 0.15 \\
Mineral premix & 0.15 \\
Calculated composition & \\
ME (kcal/kg) & 2819 \\
CP (\%) & 20.5 \\
Dig Lys (\%) & 1.08 \\
Dig Met (\%) & 0.35 \\
Dig Met+Cys (\%) & 0.75 \\
Dig Thr (\%) & 0.79 \\
Ca (\%) & 3 \\
Available P (\%) & 0.40 \\
\hline
\end{tabular}

$\mathrm{CP}$, crude protein; ME, metabolizable energy.

${ }^{1}$ Each $\mathrm{kg}$ of vitamin premix contains $6,000,000 \mathrm{IU}$ vit A; 600,000 IU vit $\mathrm{D}_{3} ; 20,000 \mathrm{IU}$ vit $\mathrm{E} ; 2 \mathrm{~g}$ vit $\mathrm{K} ; 1.2 \mathrm{~g}$ vit $\mathrm{B}_{1} ; 2.4 \mathrm{~g}$ vit $\mathrm{B}_{2} ; 2 \mathrm{~g}$ vit $\mathrm{B}_{6} ; 12 \mathrm{mg}$ vit $\mathrm{B}_{12} ; 10 \mathrm{~g}$ niasin; $300 \mathrm{mg}$ folic acid; $4 \mathrm{~g}$ calcium panthotenate; $50 \mathrm{mg}$ D-Biotin.

${ }^{2}$ Each g of mineral premix contains $80 \mathrm{~g} \mathrm{Mn} ; 30 \mathrm{~g} \mathrm{Fe} ; 60 \mathrm{~g} \mathrm{Zn} ; 5 \mathrm{~g} \mathrm{Cu}$; $0.5 \mathrm{~g} \mathrm{Co} ; 2 \mathrm{~g} \mathrm{I} ; 235.68 \mathrm{~g} \mathrm{Ca}$.

based on the recommendation of Iranian Council on Animal Care.

\section{Production parameters}

Prior to start of the experiment, two weeks preexperimental feed was given to quails for adaptation. The production parameters measured were hen day egg production (EP, \%), egg weight (EW, g), FC (g/week) and FCR. FC was calculated as the average of each replicate and the FCR was expressed as grams of feed consumed per gram of egg produced (g feed/g egg). Daily EP and EW (g) were recorded during 6 weeks. Treatment means for these traits were not different at the start of experiment $(p>0.05)$. Mass EP was calculated (EW $\times \mathrm{EP})$, accordingly.

\section{Egg characteristics}

At the end of the experiment (week 42), ten eggs per treatment (two eggs per replicate) were randomly chosen, examined and measured for eggshell thickness ( $\mathrm{mm}$ ), eggshell strength $\left(\mathrm{kgf} / \mathrm{cm}^{2}\right)$, albumen $(\mathrm{mm})$, Haugh unit scores and eggshell weight (g). Eggshell thickness (without inner and outer shell membranes) was measured at 3 different points (top, middle, and bottom) using an 
ultrasonic micrometer (Sanovo Technology A/S, Odense NV, Denmark) without cracking the eggshell. Likewise, eggshell thickness was calculated from the middle of the egg using a micrometer instrument (Norouzi et al., 2013). Albumen (height) was measured using standard micrometer (CE 300). The Haugh unit score was calculated using Roush's formula (Roush, 1981). Eggshell weight was measured after depleting internal contents and placing them at room temperature for $48 \mathrm{~h}$ by digital pan balance with $0.001 \mathrm{~g}$ accuracy.

\section{Serum biochemical parameters}

At the end of the experiment (week 42), ten quails per treatment (two quails per pen) were selected, and individual blood samples were collected separately in non-heparinized tubes. The serum was separated, stored at $-20^{\circ} \mathrm{C}$ for the further use and later was analyzed for glucose, cholesterol, LDL, HDL, alanine transaminase (ALT), gamma glutamyltransferase (GGT), alkaline phosphatase (ALP), and triglyceride by enzyme-linked immunosorbent assay technique using commercial kits (Boehringer Mannheim Hitachi 704 automatic analyzer, Tokyo, Japan). The methodology and the set of reagents for each parameter were recommended by the manufacturer of the analyzer system. Treatment-wise means of values were computed and presented.

\section{Intestinal morphology parameters}

At the end of the trial, upon obtaining the permission of Ethical Committee of the University, ten birds from each treatment (two quails per replicate) were randomly selected, stunned and killed by cutting the jugular vein. The abdominal cavity was then opened and the digestive tract with contents was removed aseptically and each carcass was subjected to detailed postmortem examination. Ileum tissue samples were separated from the Meckel's diverticulum up to $1 \mathrm{~cm}$ proximal to the ileocecal junction and then dried with desiccant paper. A 2-cm section of ileum was taken from the middle of the ileum and gently flushed with phosphate-buffered saline $(\mathrm{pH} 7.2)$. Tissue sections were immediately fixed in 10\% neutral buffered formalin and changed 3 times to complete the fixation process. A single $0.5 \mathrm{~cm}$ sample was cut from each ileal section, dehydrated with increasing concentrations $(70 \%, 80 \%, 95 \%$, and $100 \%)$ of ethanol, cleared with xylene and placed into polyfin embedding wax. Tissue sections $(2 \mu \mathrm{m})$ were cut by microtome (Leitz-1512 Microtome, Leitz, Wetzlar, Germany), floated onto slides and stained with hematoxylin (Gill no. 2, Sigma, St. Louis, MO, USA) and eosin (Sigma). To measure villus height and crypt depth, images from samples were taken using a digital camera with light microscopy. Twelve images from 4 tissue sections of each ileal section were taken and 24 villus heights and crypt depths were measured by imaging software. Measurements for each villus length were taken from the tip of the villus to the valley and measurements for crypt depth were taken from the valley to the basolateral membrane (Xu et al., 2003). For determining the number of goblet cells in $1 \mathrm{~mm}$ of villus length, all samples were dehydrated in ethanol and embedded in paraffin wax. Sections were stained with Alcian blue and periodic acid-Schiff to visualize goblet cells (Rohana and Thomas, 2009).

\section{Selected intestinal bacterial population}

To determine the changes in some selected microbial populations in the gastrointestinal tract of quails at week 42, cecal contents immediately after killing the quails were gently collected in sterile sampling tube and transferred on ice to the laboratory for microbial study. The cecal contents of each bird were pooled for serial dilution. Microbial populations were determined by serial dilution $\left(10^{-4}\right.$ to $\left.10^{-6}\right)$ of cecal samples in anaerobic diluents before inoculation onto Petri dishes of sterile agar as described by Bryant and Burkey (1953). E. coli was grown on eosin methylene blue agar, Salmonella in Salmonella Shigella (Merck, Darmstadt, Germany) and Coliforms on McConkey agar (Darmstadt, Germany). E. coli was incubated aerobically at $37^{\circ} \mathrm{C}$. Plates were counted between 24 and $48 \mathrm{~h}$ after inoculation. Colony forming units were defined as distinct colonies measuring at least $1 \mathrm{~mm}$ in diameter. Then, 9 sterile test tubes with lids containing $9 \mathrm{~mL}$ of phosphate buffer solution as diluent were prepared. Approximately $1 \mathrm{~g}$ of the cecal contents taken by sterile swab and homogenized for $3 \mathrm{~min}$ before transferring to microbiology lab in cold condition and mixed (Bryant and Burkey, 1953). Then $1 \mathrm{ml}$ out of $10 \mathrm{~mL}$ of buffer plus cecal sample in the test tube was removed by $1,000 \mu \mathrm{L}$ sampler and was transferred to the tubes and was mixed thoroughly. Similarly, it was transferred to other new tubes and this procedure was repeated until a dilution of 9 was completed. Later, $1 \mathrm{ml}$ of contents of each test tube was transferred to one of three selective media agar in petri plates, respectively, and each petri was plate incubated in $37^{\circ} \mathrm{C}$ for $24 \mathrm{~h}$. Finally, the intestinal bacterial colony populations formed in each plate was counted and adjusted to $\times 10^{9}$ manually and then was reported.

\section{Statistical analysis}

Data were analyzed as a completely randomized design manner using the general linear model procedure of SAS (SAS Institute, 2007) for those traits which were measured only once during the experimental period. MIXED procedure of SAS (SAS Institute, 2007) was used for analysis of traits that were measured repeatedly throughout the experimental period with age considered as a new main factor and initial values considered as a covariate effect in the model. Differences between treatment means were 
tested using Duncan's multiple comparison tests for main effects and Tukey's test for interactions. Statistical significance was declared at $\mathrm{p} \leq 0.05$.

\section{RESULTS AND DISCUSSION}

\section{Production parameters}

Mean EP, EW, FC, and FCR in control, BMD and PFA groups are shown in Table 2. In period I (weeks 37 to 39), EP and FCR values showed a significant $(\mathrm{p} \leq 0.05)$ improvement by addition of PFA, whereas, BMD group showed no significant changes compared with control. However, FCR was significantly similar in all studied treatment groups. In period II (weeks 40 to 42 ), the values for EP and FCR were significantly $(\mathrm{p} \leq 0.05)$ higher in BMD and PFA fed quails when compared with control group. In both periods, EW and FC values remained statistically nonsignificant $(\mathrm{p} \leq 0.05)$.

In current experiment, the PFA treated group consumed a similar amount of feed while producing more eggs due to utilization of feed more efficiently than control. In many previous studies - in agreement to our findings - addition of phytogenic/herbal compounds showed performance and FCR improvements (Sahin et al., 2010) and a better economic efficiency in Japanese quails (Christaki et al., 2011), commercial broilers (Tiihonen et al., 2010) and laying hens and broiler breeders (Bozkurt et al., 2012). However, these findings contradict some other reports (Bölükbaşi et al., 2008). In current experiment, EW did not vary among different treatments. These findings are in accordance with those of Bozkurt et al. (2012). In contrast, increased EW of layer hens by addition of essential oils has been reported by Bölükbaşi et al. (2008).

While exploring the current experiment data, it is worth mentioning that in period II, the EP drastically decreased compared with period I. This is also mainly due to the aging of the quails, though many factors like stock density, nutritional manipulation and environmental conditions can be the cause for these changes. González (1995) reported that the quail EP was significantly lowered by advancing quail age.

The PFA product used in this study contains phytomolecules (allicin, carvacrol, paprika, cinnamaldehyde, peppermint, and thymol) and organic acids (propionic acid and fumaric acid). The possible mechanism of action of herbal components might be due to the increased digestibility and improved utilization of feed thanks to their antioxidant properties and phenolic compounds. The intestinal availability of essential nutrients may result in better absorption through stimulating the secretion of pancreatic and endogenous digestive enzymes (Lovkova et al., 2001). In addition, the active substances of essential oils present in PFA had a diversifying power to synergistically improve nutrient utilization. As a result, energy and protein digestibilities are improved leading to optimized performance of laying quails (Sultan et al., 2015). Some other possible ways include increasing feed palatability due to their aromatic characteristics which promote FC, regulating of the gut microbial flora through changing the gastrointestinal bacterial load and modifying mucin biosynthesis (Windisch et al., 2008). On the other hand, organic acids present in PFA may favorably affect the host by lowering $\mathrm{pH}$ through inhibiting the pathogenic intestinal bacteria and decreasing the level of their toxic products. Modulation of the gut microbiota has a critical role in maintaining host health (Tollba et al., 2012). Organic acid in combination with essential oil showed beneficial impacts on digestive enzyme activities of both pancreas and intestinal mucosa, leading to increased growth performance of broilers (Jang et al., 2007). In turkeys, a mixture of essential oils with a blend of organic acids increased body weight and decreased FCR (Mikulski et al., 2008). The boosting effect of BMD could be attributed to the active ingredients of bacitracin which can inhibit the synthesis of bacterial cell membrane of gram positive bacteria. BMD can also enhance the antibacterial activity and increase the

Table 2. Effect of dietary feed additives on performance parameters of layer Japanese quail ( 37 to 42 weeks of age)

\begin{tabular}{|c|c|c|c|c|c|c|c|c|c|}
\hline \multicolumn{2}{|c|}{ Treatments } & \multicolumn{2}{|c|}{$\begin{array}{c}\text { Egg production* } \\
(\%)\end{array}$} & \multicolumn{2}{|c|}{$\begin{array}{l}\text { Egg weight } \\
\text { (g) }\end{array}$} & \multicolumn{2}{|c|}{$\begin{array}{l}\text { Feed consumption } \\
\text { (g/week) }\end{array}$} & \multicolumn{2}{|c|}{$\begin{array}{l}\text { Feed conversion ratio } \\
\text { ( } \mathrm{g} \text { feed } / \mathrm{g} \text { egg) }\end{array}$} \\
\hline$\overline{B M D}$ & PFA & 37-39 week & 40-42 week & 37-39 week & 40-42 week & 37-39 week & 40-42 week & 37-39 week & 40-42 week \\
\hline$\overline{0}$ & 0 & $72.73^{\mathrm{bc}}$ & $66.14^{\mathrm{c}}$ & 11.54 & 11.74 & 322.30 & 323.50 & $2.46^{\mathrm{a}}$ & $2.72^{\mathrm{a}}$ \\
\hline $0.05 \%$ & 0 & $77.20^{\mathrm{a}}$ & $73.76^{\mathrm{a}}$ & 11.93 & 11.83 & 321.70 & 320.33 & $2.22^{\mathrm{b}}$ & $2.30^{\mathrm{b}}$ \\
\hline 0 & $0.1 \%$ & $74.47^{\mathrm{b}}$ & $71.92^{b}$ & 11.85 & 11.82 & 320.25 & 331.28 & $2.31^{\mathrm{ab}}$ & $2.44^{\mathrm{b}}$ \\
\hline \multicolumn{10}{|l|}{ ANOVA } \\
\hline SEM & & 0.525 & 0.810 & 0.181 & 0.136 & 13.992 & 17.986 & 0.037 & 0.058 \\
\hline $\mathrm{p}$ value & & $\leq 0.0001$ & $\leq 0.0001$ & 0.6800 & 0.9654 & 0.0721 & 0.0625 & 0.0195 & 0.0040 \\
\hline
\end{tabular}

BMD, bacitracin methylene disalicylate (antibiotic growth promoter); PFA, phytogenic feed additive; ANOVA, analysis of variance; SEM, pooled standard error of column wise means comparison.

* Hen day mass egg production $(\%)$.

Feed conversion ratio was calculated as kilograms of feed consumed per kilogram of egg produced.

Means with different letters within the same column are significantly different $(p \leq 0.05)$. 
product stability after combination with bacitracin (Attia et al., 2003).

\section{Egg characteristics}

The effect of BMD and PFA supplementation on the egg quality parameters of quails at 42 weeks of age is given in Table 3. Notably, eggshell thickness was not influenced by dietary treatments; whereas, eggshell strength and eggshell weight were increased and albumen and Haugh unit scores were reduced significantly $(\mathrm{p} \leq 0.05)$ by addition of PFA into the basal diet. Incorporation of BMD also revealed almost similar results with PFA, when compared with control group. PFA was found to be more effective than BMD at the end of trial (week 42).

Previous literature reveals contradictory results about the effects of herbal feed additives/phytogenic components on egg quality characteristics of laying birds. It was reported that Haugh unit scores, shell thickness, eggshell weight, yolk color, yolk weight and albumen and yolk indices were not altered by supplementing essential oils into the daily diet of laying quails (Bozkurt et al., 2012). The achievement on eggshell strength in current study is supported by the findings of Kaya et al. (2013), who reported that plant extract of Origanum vulgare, Thymus vulgaris, thyme oil, origanum oil, garlic oil, anise oil and fennel oil enhanced eggshell strength and eggshell thickness. However, Bozkurt et al. (2012) reported that essential oils supplementation had no effect on eggshell strength and eggshell thickness of laying hens.

There are several factors influencing the quality characteristics of quail eggs. The improvement of the eggshell strength found in current trial by consumption of PFA in quails could be attributed to the stimulatory role of the essential oils on enzymes secretion and amino acids production, which are required for the formation of eggshell (Nazligul et al., 2001). Digestibility of most amino acids in ileum may increase by addition of essential oils into the diet (Maenner et al., 2011). The other possible reason is the influence of essential oils on the metabolic activity of beneficial bacteria, within the intestine, which positively influences mineral absorption rate, especially those of $\mathrm{Ca}^{2+}$ and $\mathrm{Mg}^{2+}$ (Roberfroid, 2000).

On the other hand, organic acids may affect the integrity of microbial cell membranes and interfere with nutrient transport and energy metabolism (Hedayati et al., 2014). It is also believed that lactic acid may decrease pathogenic microorganisms in the crop leading to less competition for nutrients between quails and bacteria. In addition, there is a report stating the lactic acid is palatable for birds which increases FC leading to enhance egg quality characteristics (Laury et al., 2009). More so, it is presumed that the organic acid mixture contributes to the production of longer and wider quail eggs with thicker shells, larger surface areas and increased breaking strength in quails.

\section{Serum biochemical parameters}

The effect of BMD and PFA feed supplements on the blood biochemical parameters of laying quails are presented in Table 4. It was found that PFA addition significantly $(p \leq 0.05)$ decreased cholesterol, LDL, HDL, ALP, and triglyceride. By contrast, increased GGT levels were observed by inclusion of PFA with no impact on ALT levels, compared with control group. Likewise, the BMD also showed less effectiveness than PFA on all above-mentioned parameters. The glucose content was significantly $(\mathrm{p} \leq 0.05)$ decreased in BMD group and remained unchanged among PFA and control treatments, but it was significantly higher in PFA than control and BMD fed groups.

In many studies, it is reported that essential oils from different plant origins have increased serum triglyceride, total cholesterol and glucose of Japanese quail (Soltan et al., 2008; Khaksar et al. 2012). In contrary, there is evidence of reduced serum cholesterol, plasma triglyceride and phospholipids in birds with the incorporation of plant derivatives into the diets (Babazadeh et al., 2011).

Previous reports have demonstrated the antioxidant and antimicrobial activity roles of PFA. Furthermore, other effects such as anti-inflammatory, anti-fungal, antiinfectious and anti-toxigenic have been reported in many studies (Swiatkiewicz and Arczewska-Wlosek, 2012). Blood metabolites indices of liver, renal functions and hematological contents may provide good instances of

Table 3. Effect of dietary feed additives on egg characteristics of layer Japanese quail at 42 weeks of age

\begin{tabular}{lcccccc}
\hline Treatments & PFA & $\begin{array}{c}\text { Eggshell thickness } \\
(\mathrm{mm})\end{array}$ & $\begin{array}{c}\text { Eggshell strength } \\
\left(\mathrm{kgf} / \mathrm{cm}^{2}\right)\end{array}$ & $\begin{array}{c}\text { Albumen height } \\
(\mathrm{mm})\end{array}$ & Haugh unit & Eggshell weight $(\mathrm{g})$ \\
\hline BMD & 0 & 0.20 & $2.10^{\mathrm{b}}$ & $4.91^{\mathrm{a}}$ & $91.33^{\mathrm{a}}$ & $1.08^{\mathrm{b}}$ \\
$0.05 \%$ & 0 & 0.20 & $2.26^{\mathrm{a}}$ & $4.24^{\mathrm{c}}$ & $86.10^{\mathrm{c}}$ & $1.14^{\mathrm{a}}$ \\
0 & 0.22 & $2.28^{\mathrm{a}}$ & $4.46^{\mathrm{b}}$ & $89.33^{\mathrm{b}}$ & $1.13^{\mathrm{a}}$ \\
ANOVA & & & & & \\
$\quad$ SEM & & 0.010 & 0.26 & 0.79 & 0.552 & 0.10 \\
$\quad$ p value & & 0.4413 & 0.0132 & $\leq 0.0001$ & $\leq 0.0001$ & 0.0067 \\
\hline
\end{tabular}

BMD, bacitracin methylene disalicylate (antibiotic growth promoter); PFA, phytogenic feed additive; ANOVA, analysis of variance; SEM, pooled standard error of column wise means comparison.

Means with different letters within the same column are significantly different $(\mathrm{p} \leq 0.05)$. 
Table 4. Effect of dietary feed additives on serum biochemical of layer Japanese quail at 42 weeks of age

\begin{tabular}{|c|c|c|c|c|c|c|c|c|c|}
\hline \multicolumn{2}{|c|}{ Treatments } & \multirow{2}{*}{$\begin{array}{l}\text { Glucose } \\
(\mathrm{mg} / \mathrm{dL})\end{array}$} & \multirow{2}{*}{$\begin{array}{c}\text { Cholesterol } \\
(\mathrm{mg} / \mathrm{dL})\end{array}$} & \multirow{2}{*}{$\begin{array}{c}\text { LDL } \\
(\mathrm{mg} / \mathrm{dL})\end{array}$} & \multirow{2}{*}{$\begin{array}{c}\text { HDL } \\
(\mathrm{mg} / \mathrm{dL})\end{array}$} & \multirow{2}{*}{$\begin{array}{c}\text { ALT } \\
(\mathrm{Iu} / \mathrm{L})\end{array}$} & \multirow{2}{*}{$\begin{array}{l}\text { GGT } \\
(\mathrm{Iu} / \mathrm{L})\end{array}$} & \multirow{2}{*}{$\begin{array}{l}\text { ALP } \\
(\mathrm{U} / \mathrm{L})\end{array}$} & \multirow{2}{*}{$\begin{array}{c}\text { Triglyceride } \\
(\mathrm{mg} / \mathrm{dL})\end{array}$} \\
\hline BMD & PFA & & & & & & & & \\
\hline 0 & 0 & $304.29^{\mathrm{a}}$ & $356.04^{\mathrm{a}}$ & $115.45^{\mathrm{a}}$ & $99.33^{\mathrm{a}}$ & $2.01^{\mathrm{a}}$ & $264.13^{\mathrm{b}}$ & $3,660.67^{\mathrm{a}}$ & $382.32^{\mathrm{a}}$ \\
\hline $0.05 \%$ & 0 & $293.50^{b}$ & $224.52^{\mathrm{b}}$ & $98.20^{\mathrm{b}}$ & $96.78^{\mathrm{b}}$ & $2.01^{\mathrm{a}}$ & $300.33^{\mathrm{a}}$ & $2,997.04^{\mathrm{b}}$ & $293.11^{b}$ \\
\hline 0 & $0.1 \%$ & $304.65^{\mathrm{a}}$ & $218.24^{\mathrm{c}}$ & $84.29^{c}$ & $90.81^{\mathrm{c}}$ & $1.95^{\mathrm{b}}$ & $253.66^{\mathrm{c}}$ & $2,486.83^{\mathrm{c}}$ & $281.67^{\mathrm{c}}$ \\
\hline \multicolumn{10}{|c|}{ ANOVA } \\
\hline SEN & & 1.26 & 6.25 & 3.09 & 0.97 & 0.01 & 3.20 & 116.81 & 3.42 \\
\hline$p$ va & & $\leq 0.0001$ & $\leq 0.0001$ & $\leq 0.0001$ & $\leq 0.0001$ & 0.0032 & $\leq 0.0001$ & $\leq 0.0001$ & $\leq 0.0001$ \\
\hline
\end{tabular}

LDL, low-density lipoprotein; HDL, high-density lipoprotein; ALT, alanine aminotransferase; GGT, gamma-glutamyltransferase; ALP, alkaline phosphatase; BMD, bacitracin methylene disalicylate (antibiotic growth promoter); PFA, phytogenic feed additive; ANOVA, analysis of variance; SEM, pooled standard error of column wise means comparison.

Means with different letters within the same column are significantly different $(\mathrm{p} \leq 0.05)$.

animal health status and physiological condition (Toghyani et al., 2010). The lipophilic property and chemical structure of phenolic compounds present in PFA could play a role in manipulation of the enzyme activities inside the body of broilers (Attia et al., 2003). The lower serum cholesterol content may be the result of an increased lipid digestibility due to a higher secretion of bile and digestive enzymes indicating enhanced nutrient supply and transport (Manafi, 2015). The increased nutrient supply for growth is reflected in enhanced nutrient transport in the blood. Moreover, the PFA could cause a circulatory enzyme elevation. Generally GGT and ALT are considered as liver enzymes which are increased at the time of liver damage (heptato-cellular degeneration), so the decrease in these enzymes may provide proof for the occurrence of hepato-protective effect of essential oils present in PFA. Brenes and Roura (2010) have reported that serum total protein, albumin concentrations and AST activities significantly enhanced in laying hens receiving organic acids but lipid metabolism markers (cholesterol, HDL, LDL, triglyceride, and total lipid concentrations) remained unchanged. The glucose level in blood samples is a biochemical indicator of stress that decreases in quails fed PFA compared with BMD in current study and could be justified by the stress-lowering effect of this feed additive (Yesilbag and Coplan, 2006).

\section{Morphology of intestine}

This study revealed a significant $(\mathrm{p} \leq 0.05)$ increase in illeal villus height and villus height to crypt depth ratio $(\mathrm{VH} / \mathrm{CD})$, decrease in crypt depth and number of goblet cell in $1 \mathrm{~mm}$ of villus height in quails fed both PFA and BMD, compared to respected control groups (Table 5). The variation between the data of different treatments and studied parameters are more evident in PFA fed group.

The findings of present experiment in intestinal morphology parameters are in consistence with reports of Adibmoradi et al. (2006), who stated that jejunal villus height was increased and crypt depth was decreased leading to increased villus height to crypt depth ratio in birds fed graded levels of garlic in the diet. In contrast, some reports stating that the addition of essential oils did not affect villus height (Jamroz et al., 2006; Reisinger et al., 2011). Moreover, Garcia et al. (2007) reported an increase in crypt depth when essential oil was supplemented into the broiler diet. In contrast to our results, inclusion of essential oils in the diet of broilers increased goblet cell numbers reported by Garcia et al. (2007), Reisinger et al. (2011).

Villus height and crypt depth are considered as indicators of a well-functioning intestine. Increased villus height provides a bigger surface area for nutrients absorption and therefore performance enhancement (Awad et al., 2008). On the other hand, a drop in villus height can

Table 5. Effect of dietary feed additives on morphology of intestine of layer Japanese quail at 42 weeks of age

\begin{tabular}{|c|c|c|c|c|c|}
\hline \multicolumn{2}{|l|}{ Treatments } & \multirow{2}{*}{$\begin{array}{l}\text { Villus height } \\
\qquad(\mu \mathrm{m})\end{array}$} & \multirow{2}{*}{ Number of goblet cells ${ }^{1}$} & \multirow{2}{*}{$\begin{array}{l}\text { Crypt depth } \\
\qquad(\mu \mathrm{m})\end{array}$} & \multirow{2}{*}{$\begin{array}{c}\text { Villus height to crypt } \\
\text { depth ratio }\end{array}$} \\
\hline $\mathrm{BMD}$ & PFA & & & & \\
\hline 0 & 0 & $5.14^{\mathrm{b}}$ & $10.19^{\mathrm{a}}$ & $0.96^{\mathrm{a}}$ & $5.34^{\mathrm{c}}$ \\
\hline $0.05 \%$ & 0 & $6.48^{\mathrm{a}}$ & $9.29^{\mathrm{b}}$ & $0.76^{\mathrm{b}}$ & $8.51^{\mathrm{a}}$ \\
\hline 0 & $0.1 \%$ & $6.16^{\mathrm{a}}$ & $9.38^{\mathrm{b}}$ & $0.79^{\mathrm{b}}$ & $8.81^{\mathrm{b}}$ \\
\hline \multicolumn{6}{|l|}{ ANOVA } \\
\hline SEM & & 0.155 & 0.104 & 0.024 & 0.034 \\
\hline $\mathrm{p}$ value & & $\leq 0.0001$ & $\leq 0.0001$ & $\leq 0.0001$ & $\leq 0.0001$ \\
\hline
\end{tabular}

BMD, bacitracin methylene disalicylate (antibiotic growth promoter); PFA, phytogenic feed additive; ANOVA, analysis of variance; SEM, pooled standard error of column wise means comparison.

${ }^{1}$ Number of goblet cells in each $1 \mathrm{~mm}$ of villus length.

Means with different letters within the same column are significantly different $(\mathrm{p} \leq 0.05)$. 
reduce nutrient absorption by decreasing the intestinal surface area for absorption. Hence, reduction in nutrient absorption will lead to decreased resistance to diseases and diminished performance. Escalation in secretion of digestive tract is the negative consequence of deeper crypt and shorter villi (Xu et al., 2003). Goblet cells are liable for the production of intestinal mucins that are the major component of the mucus layer coats of the broilers intestine. Many scientists believe that essential oils have the ability to reduce the growth of $E$. coli and $C$. perfringens and increase the numbers of Lactobacillus spp. when fed to birds (Brenes and Roura, 2010).

The PFA products stimulate gut hormones exerting diverse actions in the gastro intestinal tract leading to intestinal growth, enhancing mucosal blood flow and most importantly nutrient assimilation and thereby changing FC pattern by providing a feedback signal to the brain (Guban et al., 2006). On the subject of the intestinal morphology, normally, heavier broilers are linked with longer villi, greater villus width and higher villus surface area (Adibmoradi et al., 2006). It has been proposed that longer villi would result in an increased surface area and higher absorption of nutrients (Incharoen et al., 2010). This higher absorptive ability of the intestine in PFA fed birds is supported by higher blood nutrient concentrations. According to Yanishlieva et al. (1999), essential oils seem to have positive effects on blocking the radical chain process by interaction with peroxide radicals. Organic acids have direct effects on the poultry performance. In study of Antongiovanni et al. (2007) inclusion of organic acids in broiler diets increased the weight and length of small intestine. On the contrary, Vieira et al. (2008) reported that inclusion of some organic acids did not significantly influence the villus height at any age of broiler's life. Sultan et al. (2015) also demonstrated that organic acids improve the protein digestibility by decreasing endogenous nitrogen loss and by producing ammonia which ultimately lead to better intestinal morphological properties of birds.

\section{Selected intestinal bacterial population}

The bacterial population of intestine of quails fed BMD and PFA is shown in Table 6. Results showed that addition of BMD and PFA significantly $(\mathrm{p} \leq 0.05)$ lowered the cecal number of coliforms, Salmonella, and E. coli, with more reduction emphasis in PFA fed group. Addition of PFA decreased the population of cecal bacterial count of coliforms, Salmonella, and E. coli significantly when compared with control. At present, there are prominent studies indicating that essential oils could control the common intestinal pathogen growth of poultry (Dorman and Deans, 2000). Addition of thyme essential oil in Japanese quail diet significantly $(\mathrm{p} \leq 0.05)$ increased the number of Lactobacillus, decreased E. coli population in the
Table 6. Effect of dietary feed additives on intestinal bacterial count $\left(\times 10^{9}\right)$ of layer Japanese quail at 42 weeks of age

\begin{tabular}{lcccc}
\hline Treatments & & Coliforms & Salmonella & E. coli \\
\hline BMD & PFA & & & \\
\hline 0 & 0 & $3.55^{\mathrm{a}}$ & $7.15^{\mathrm{a}}$ & $3.25^{\mathrm{a}}$ \\
$0.05 \%$ & 0 & $2.31^{\mathrm{b}}$ & $4.25^{\mathrm{c}}$ & $2.12^{\mathrm{b}}$ \\
0 & $0.1 \%$ & $2.43^{\mathrm{b}}$ & $5.42^{\mathrm{b}}$ & $2.22^{\mathrm{b}}$ \\
ANOVA & & & & \\
$\quad$ SEM & & 0.155 & 0.292 & 0.126 \\
$\quad$ p value & & $\leq 0.0001$ & $\leq 0.0001$ & $\leq 0.0001$ \\
\hline
\end{tabular}

BMD, bacitracin methylene disalicylate (antibiotic growth promoter); PFA, phytogenic feed additive; ANOVA, analysis of variance; SEM, pooled standard error of column wise means comparison.

Means with different letters within the same column are significantly different $(\mathrm{p} \leq 0.05)$.

ileum and inhibited the growth of Salmonella typhimurium due to its antimicrobial properties (Dorman and Deans, 2000). Siragusa et al. (2008) reported that addition of Humuluslupulus decreased $C$. perfringens population in the broiler intestine. A blend of essential oils containing carvacrol and thymol is reported to have the ability to decrease E. coli and C. perfringens in broilers (Jang et al., 2007). In study of Jamroz et al. (2006), a significant reduction in $E$. coli numbers was reported following addition of natural plant extract in broiler diet. However, there are a few studies conversely reporting that dietary essential oils had no effect on the intestinal microflora populations (Hermans et al., 2011). Organic acids including short chain fatty acids (SCFAs) such as acetate, propionate and butyrate have been found to control Salmonella enteritidis, showing growth promoting impact on the beneficial intestinal microflora (Hansen et al., 1997). Positive beneficial effects of organic acids on production performance and carcass traits of broilers were reported by Leeson et al. (2005) and Antongiovanni et al. (2007).

Poultry caeca have a range of microorganisms with strong impacts on the performance and the health of broilers. Therefore, the aim of PFA addition into the diet is to create a favorable gut microflora by decreasing pathogenic bacteria (Apajalahti et al., 2001). It is assumed that gut microflora reduces nutrients availability to host animal by enforcing the intestinal cell turnover and thereby increasing the intestinal requirement for nutrients. Moreover, intestinal microflora and epithelial cells have to compete for nutrients (Dibner and Richards, 2005). A higher absorptive capacity in the intestine of PFA fed animals is also supported by higher blood nutrient concentrations of those quails, as observed in the present study. However, many factors influence the effectiveness of dietary supplementation of phyto-additives such as dose of extracts in the mucus layer in the intestine (Hermans et al., 2011). More so, fatty acids cause changes in intracellular $\mathrm{pH}$ of intestine. Butyric acid is considered the prime enterocytes energy source necessary 
for the correct development of the gut associated lymphoid tissue (Antongiovanni et al., 2007). In conclusion, the outcomes of current study revealed that this novel eubiotic feed additive having phytomolecules and organic acids as main ingredients, at an inclusion level of $0.1 \%$, did improve the performance, most of studied egg characteristics, serum biochemical parameters, immunity, morphology of intestine and reduced population of harmful bacteria in quails. It can be concluded that addition of combined bioactive components of herbal plants along with organic acid as PFA at the dosage of $0.1 \%$ can be used as an alternative to antibiotic growth promoters in laying Japanese quails.

\section{CONFLICT OF INTEREST}

We certify that there is no conflict of interest with any financial organization regarding the material discussed in the manuscript.

\section{ACKNOWLEDGMENTS}

This study was financially supported by Director of Research, Malayer University, Malayer, Iran. The authors would like to thank Mr. Reza Soleymani, laboratory staff of Department of Animal Science, Malayer University Iran for his skillful technical assistance.

\section{REFERENCES}

Adibmoradi, M., B. Navidshad, J. Seifdavati, and M. Royan. 2006. Effect of dietary garlic meal on histological structure of small intestine in broiler chickens. J. Poult. Sci. 43:378-383.

Antongiovanni, M., A. Buccioni, F. Petacchi, S. Leeson, S. Minieri, A. Martini, and R. Cecchi. 2007. Butyric acid glycerides in the diet of broiler chickens: effects on gut histology and carcass composition. Ital. J. Anim. Sci. 6:19-25.

Apajalahti, J. H. A., H. Kettunen, M. Bedford, and W. E. Holben. 2001. Percent $\mathrm{G}+\mathrm{C}$ profiling accurately reveals diet-related differences in the gastrointestinal microbial community of broiler chickens. Appl. Environ. Microbiol. 67:5656-5667.

Attia, Y. A., A. E. Tag El-Din, H. S. Zeweil, and M. A. Arafat. 2003. Nutritional evaluation of nigella seed meal and the effect of microbial phytase and amino acids supplementations on its feeding value for Japanese quail. Egypt. J. Nutr. Feeds 6:201217

Awad, W., K. Ghareeb, and J. Böhm. 2008. Intestinal structure and function of broiler chickens on diets supplemented with a synbiotic containing Enterococcus faecium and oligosaccharides. Int. J. Mol. Sci. 9:2205-2216.

Babazadeh, D., T. Vahdatpour, H., Nikpiran, M. A. Jafargholipour, and S. Vahdatpour. 2011. Effects of probiotic, prebiotic and synbiotic intake on blood enzymes and performance of Japanese quails (Coturnix japonica). Ind. J. Anim. Sci. 81:870874

Bölükbaşi, Ş. C., M. K. Erhan, and Ö. Kaynar. 2008. The effect of feeding thyme, sage and rosemary oil on laying hen performance, cholesterol and some proteins ratio of egg yolk and Escherichia coli count in feces. Arch Geflugelk. 72:231237.

Bozkurt, M., K. Küçükyilmaz, A. U. Çatli, M. Çinar, E. Bintas, and F. Çöven. 2012. Performance, egg quality, and immune response of laying hens fed diets supplemented with mannanoligosaccharide or an essential oil mixture under moderate and hot environmental conditions. Poult. Sci. 91:1379-1386.

Brenes, A. and E. Roura. 2010. Essential oils in poultry nutrition: Main effects and modes of action. Anim. Feed Sci. Technol. 158:1-14.

Bryant, M. P. and L. A. Burkey. 1953. Cultural methods and some characteristics of some of the more numerous groups of bacteria in the bovine rumen. J. Dairy Sci. 36:205-217.

Christaki, E. V., E. M. Bonos, and P. C. Florou-Paneri. 2011. Use of anise seed and/or $\alpha$-tocopheryl acetate in laying Japanese quail diets. S. Afr. J. Anim. Sci. 41:126-133.

Dibner, J. J. and J. D. Richards. 2005. Antibiotic growth promoters in agriculture: history and mode of action. Poult. Sci. 84:634643.

Dorman, H. J. and S. G. Deans. 2000. Antimicrobial agents from plants: Antibacterial activity of plant volatile oils. J. Appl. Microbiol. 88:308-316.

Garcia, V., P. Catala-Gregori, F. Hernandez, M. D. Megias, and J. Madrid. 2007. Effect of formic acid and plant extracts on growth, nutrient digestibility, intestine mucosa morphology and meat yield of broilers. J. Appl. Poult. Res. 16:555-562.

González, M. 1995. Influence of age on physical traits of Japanese quail (Coturnixcoturnix japonica) eggs. Ann. Zootec. 44:307312.

Grashorn, M. A. 2010. Use of phytobiotics in broiler nutrition - an alternative to in feed antibiotics? J. Anim. Feed Sci. 19:338347.

Guban, J., D. R. Korver, G. E. Allison, and G. W. Tannock. 2006. Relationship of dietary antimicrobial drug administration with broiler performance, decreased population levels of Lactobacillus salivarius, and reduced bile salt deconjugation in the ileum of broiler chickens. Poult. Sci. 85:2186-2194.

Hansen, L. L., A. E. Larsen, B. B. Jensen, and J. Hansen-Moller. 1997. Short time effect of zinc bacitracin and heavy fouling with faeces plus urine on boar taint. J. Anim. Sci. 64:351-363.

Hedayati, M., M. Manafi, M. Yari, and A. Avara. 2014. The influence of an Acidifier feed additive on biochemical parameters and immune response of broilers. Annu. Res. Rev. Biol. 4:1637-1645.

Hermans, D., A. Martel, K. van Deun, F. van Immerseel, M. Heyndrickx, F. Haesebrouck, and F. Pasmans. 2011. The cinnamon-oil ingredient trans-cinnamaldehyde fails to target Campylobacter jejuni strain $\mathrm{KC} 40$ in the broiler chicken cecum despite marked in vitro activity. J. Food Prot. 74:17291734.

Incharoen, T., K. Yamauchi, T. Erikawa, and H. Gotoh. 2010. Histology of intestinal villi and epithelial cells in chickens fed low-protein or low-crude fat diets. Ital. J. Anim. Sci. 9:e82.

Jamroz, D., T. Wertelecki, M. Houszka, and C. Kamel. 2006. Influence of diet type on the inclusion of plant origin active substances on morphological and histochemical characteristics 
of the stomach and jejunum walls in chicken. J. Anim. Physiol. Anim. Nutr. 90:255-268.

Jang I. S., Y. H. Ko, S. Y. Kang, and C. Y. Lee. 2007. Effect of commercial essential oils on growth performance, digestive enzyme activity, and intestinal microflora population in broiler chickens. Anim. Feed Sci. Technol. 134:304-315.

Kaya, A., H. Kaya, M. Macit, S. Celebi, N. Esenbuga, M. A. Yoruk, and M. Karaoglu. 2013. Effects of dietary inclusion of plant extract mixture and copper into layer diets on egg yield and quality, yolk cholesterol and fatty acid composition. Kafkas Univ. Vet. Fak. Derg. 19:673-679.

Khaksar, V., M. van Krimpen, H. Hashemipour, and M. Pilevar. 2012. Effects of thyme essential oil on performance, some blood parameters and ilealmicroflora of Japanese quail. J. Poult. Sci. 49:106-110.

Laury, A. M., M. V. Alvarado, G. Nace, C. Z. Alvarado, J. C. Brooks, A. Echeverry, and M. M. Brashears. 2009. Validation of a lactic acid- and citric acid-based antimicrobial product for the reduction of Escherichia coli O157: H7 and Salmonella on beef tips and whole chicken carcasses. J. Food Prot. 72:22082211.

Leeson, S., H. Namkung, M. Antongiovanni, and E. H. Lee. 2005. Effect of butyric acid on the performance and carcass yield of broiler chickens. Poult. Sci. 84:1418-1422.

Lovkova, M. Y., G. N. Buzuk, S. M. Sokolova, and N. I. Kliment'eva. 2001. Chemical features of medicinal plants (Review). Appl. Biochem. Microbiol. 37:229-237.

Maenner, K., W. Vahjen, and O. Simon. 2011. Studies on the effects of essential-oil-based feed additives on performance, ileal nutrient digestibility, and selected bacterial groups in the gastrointestinal tract of piglets. J. Anim. Sci. 89:2106-2112.

Manafi, M. 2015. Comparison study of a natural non-antibiotic growth promoter and a commercial probiotic on growth performance, immune response and biochemical parameters of broiler chicks. J. Poult. Sci. 52:274-281.

Mikulski, D., Z. Zduńczyk, J. Jankowski, and J. Juśkiewicz. 2008. Effects of organic acids or natural plant extracts added to diets for turkeys on growth performance, gastrointestinal tract metabolism and carcass characteristics. J. Anim. Feed Sci. 17:233-246.

Nazligul, A., K. Turkyilmaz, and H. E. Bardakçioglu. 2001. A study on some production traits and egg quality characteristics of Japanese quail. Turk. J. Vet. Anim. Sci. 25:1007-1013.

Norouzi, S., A. Yaghobfar, M. Shokrpour, and A. Safamehr. 2013. Determination of nutritive value and effect of different levels of prosopis juliflora pods on performance of laying hens. Res. Anim. Prod. 4:62-77.

Reisinger, N., T. Steiner, S. Nitsch, G. Schatzmayr, and T. J. Applegate. 2011. Effects of a blend of essential oils on broiler performance and intestinal morphology during coccidial vaccine exposure. J. Appl. Poult. Res. 20:272-283.

Roberfroid, M. B. 2000. Prebiotics and probiotics: are they functional foods? Am. J. Clin. Nutr. 71:1682S-1687S.

Rohana, A. and F. Thomas. 2009. Thermotolerance-induced goblet cell activity confers protection in post-operative gut barrier dysfunction. Int. J. Surg. 7:237-242.

Roush, W. B. 1981. TI 159 calculator program for Haugh unit calculation. Poult. Sci. 60:1086-1088.
Sahin, K., C. Orhan, M. Tuzcu, S. Ali, N. Sahin, and A. Hayirli. 2010. Epigallocatechin-3-gallate prevents lipid peroxidation and enhances antioxidant defense system via modulating hepatic nuclear transcription factors in heat-stressed quails. Poult. Sci. 89:2251-2258.

SAS Institute. 2007. SAS/STAT User's Guide. Version 9.2 edn. SAS Institute Inc., Cary, NC. USA.

Siragusa, G. R., G. J. Haas, P. D. Matthews, R. J. Smith, R. J. Buhr, N. M. Dale, and M. G. Wise. 2008. Antimicrobial activity of lupulone against Clostridium perfringens in the chicken intestinal tract jejunum and caecum. J. Antimicrob. Chemother. 61:853-858.

Soltan, M. A., R. S. Shewita, and M. I. El-Katcha. 2008. Effect of dietary anise seeds supplementation on growth performance, immune response, carcass traits and some blood parameters of broiler chickens. Int. J. Poult. Sci. 7:1078-1088.

Stanaćev, V., D. Glamočić, N. Milošević, N. Puvača, V. Stanaćev, and N. Plavša. 2011. Effect of garlic (Allium sativum L.) in fattening chicks nutrition. Afr. J. Agric. Res. 6:943-948.

Sultan, A., T. Ullah, S. Khan, and R. U. Khan. 2015. Effect of organic acid supplementation on the performance and ileal microflora of broiler during finishing period. Pak. J. Zool. 47:635-639.

Swiatkiewicz, S. and A. Arczewska-Wlosek. 2012. Prebiotic fructans and organic acids as feed additives improving mineral availability. World's Poult. Sci. J. 68:269-279.

Tiihonen, K., H. Kettunen, M. H. Bento, M. Saarinen, S. Lahtinen, A. C. Ouwehand, H. Schulze, and N. Rautonen. 2010. The effect of feeding essential oils on broiler performance and gut microbiota. Br. Poult. Sci. 51:381-392.

Toghyani, M., M. Toghyani, A. Gheisari, G. Ghalamkari, and M. Mohammadrezaei. 2010. Growth performance, serum biochemistry and blood hematology of broiler chicks fed different levels of black seed (Nigella sativa) and peppermint (Mentha piperita). Livest. Sci. 129:173-178.

Tollba, A. A. H., S. A. M. Shabaan, and M. A. A. Abdel-Mageed. 2012. Effects of using aromatic herbal extract and blended with organic acids on productive and physiological performance of poultry. Egypt. Poult. Sci. J. 30:229-248.

Vieira, S. L., O. A. Oyarzabal, D. M. Freitas, J. Berres, J. E. M. Peña, C. A. Torres, and J. L. B. Coneglian. 2008. Performance of broilers fed diets supplemented with sanguinarine-like alkaloids and organic acids. J. Appl. Poult. Res. 17:128-133.

Windisch, W., K. Schedle, C. Plitzner, and A. Kroismayr. 2008. Use of phytogenic products as feed additives for swine and poultry. J. Anim. Sci. 86:140-148.

Xu, Z. R., C. H. Hu, M. S. Xia, X. A. Zhan, and M. Q. Wang. 2003. Effects of dietary fructooligosaccharide on digestive enzyme activities, intestinal microflora and morphology of male broilers. Poult. Sci. 82:1030-1036.

Yanishlieva, N. V, E. M. Marinova, M. H. Gordon, and V. G. Raneva. 1999. Antioxidant activity and mechanism of action of thymol and carvacrol in two lipid systems. Food Chem. 64:5966.

Yesilbag, D. and I. Çolpan. 2006. Effects of organic acid supplemented diets on growth performance, egg production and quality and on serum parameters in laying hens. Rev. Med. Vet. 157:280-284 